Board of Governors of the Federal Reserve System

International Finance Discussion Papers

Number 570

October 1996

\title{
THE REACTION OF EXCHANGE RATES AND INTEREST RATES \\ TO NEWS RELEASES
}

Hali J. Edison

NOTE: International Finance Discussion Papers are preliminary materials circulated to stimulate discussion and critical comment. References in publications to International Finance Discussion Papers (other than an acknowledgement that the writer has had access to unpublished material) should be cleared with the author or authors. 


\begin{abstract}
This paper examines the response of exchange rates and interest rates -- U.S. and foreign -- to economic news. The news is associated with the surprise component of the monthly release of six U.S. macroeconomic variables. The results suggest that dollar exchange rates systematically react to news about real economic activity -- a surprise of 100,000 on nonfarm payroll employment leads to a 0.2 percent appreciation of the exchange rate. In general, exchange rates do not react systematically to news on inflation. By contrast, U.S. interest rates respond to both types of news, although the response continues to be extremely small, on the order of 1 to 2 basis points. Finally, Japanese interest rates systematically react, but to a very minor extent, to news about U.S. real economic activity, while German rates, in general, do not.
\end{abstract}




\section{The Reaction of Exchange Rates and Interest Rates to News Releases}

Hali J. Edison'

\section{Introduction}

The effects of economic news on exchange rates and interest rates have received considerable attention in both the research literature and the financial press in the last few years. Examining the response of asset prices to news enables one to test different hypotheses. This approach has become increasingly popular, especially for exchange rates, as they have proven to be difficult to model. The primary focus of this paper is to examine the reaction of U.S. interest rates and the mark/dollar and yen/dollar exchange rates to macroeconomic news. The news is associated with the monthly release of six U.S. macroeconomic variables that have been classified into two categories: unexpected inflation and unexpected change in economic activity.

The first category of economic news relates to unexpected inflation as measured by the unexpected parts of the monthly announcement of the rate of change of the consumer price index (CPI) and the producer price index (PPI). It is the impact of these surprises on agents' expectations that determine the response of exchange rates and interest rates. If announced inflation rates are higher than expected, and expectations of future inflation therefore rise higher, then this may cause -after the announcement -- nominal interest rates to rise and the dollar to depreciate. Alternatively, a second channel through which an inflation surprise may affect rates occurs if agents believe the monetary authorities will react to inflation news. Under this scenario, unexpectedly high inflation may lead to a tighter-than-otherwise monetary policy, and this would lead to higher interest rates and an appreciation of the dollar. Thus, the sign on inflation news is a priori ambiguous for exchange rates and positive for interest rates.

The second category of economic news relates to unexpected changes in economic activity as measured by the unexpected components of changes in the index of industrial production (IP), retail sales (RS), unemployment rates (UN), nonfarm payroll employment (NF). Once again there are two channels through which unexpected growth, as indicated by unexpected increases in IP, RS, NF or a decline in $\mathrm{UN}$, can affect exchange rates and interest rates. First, signs of unexpected growth might lead agents to revise their expectations of real growth upward, which leads to an upward revision of

\footnotetext{
${ }^{1}$ The author is a senior economist in the Division of International Finance, Board of Governors of the Federal Reserve System. I would like to thank Athanasios Orphanides for providing me with the data and his general advice. I would also like to thank Steven Braun, Jon Faust, Karen Johnson, James Kennedy, Jeffrey Shafer, and Ralph Smith for helpful discussions. I thank Alexis Zarechnak for his efficient research assistance. The views expressed in this paper are solely the responsibility of the author and should not be interpreted as reflecting those of the Board of Governors of the Federal Reserve System or other members of its staff.
} 
U.S. money demand and hence an appreciation of the exchange rate or an increase in interest rates. Alternatively, if agents fear that the monetary authority will interpret this news as indicating the overheating of the economy (or one not falling into a recession) by raising (or not lowering) interest rates, then interest rates and exchange rates should rise. No matter what the channel, the sign of these news variables on both rates should be unambiguously positive.

Most previous empirical investigations of this sort have focused on the effects of U.S. announcements on bilateral dollar exchange rates and on U.S. interest rates. Spillover effects on other interest rates have been largely ignored. ${ }^{2}$ Thus, I also examine the impact of U.S. news on German and Japanese interest rates. This provides some insights into whether U.S. news has spillover effects.

Several authors have examined the response of asset prices to news, using monthly or semiannual data. For example, Dornbusch (1980), Frenkel (1981), Edwards (1982), and Rose(1984) use innovations in the interest differentials and other macroeconomic variables to model expectations and derive measures for news. There are inherent measurement problems with this approach that can be circumvented, in part, by the using actual announcements of official statistics. Several studies have looked at the response of interest rates and exchange rates to news embodied in these announcements. For example, Engel and Frankel (1984) examine the reaction of the mark/dollar exchange rate to money supply announcements and find that positive money supply announcements are associated with appreciations of the dollar. Similarly, Roley and Troll (1983) and Urich and Wachtel (1984) relate U.S. macroeconomic news to U.S. interest rate movements and find that money supply announcements are strongly correlated with interest rate movements. Using a similar methodology, Hakkio and Pearce (1985) consider the response of exchange rates to announcements of U.S inflation, industrial production, and unemployment, as well as to weekly money supply announcements. They also find that money supply announcements affect exchange rates significantly. In contrast, Hardouvelis (1988) finds exchange rates react to news about money supply and trade balances systematically and occasionally to some business cycle variables. ${ }^{3}$ Ito and Roley (1987) study the reactions of the yen/dollar rate to macroeconomic announcements in the United States and Japan and find that U.S. announcements, especially U.S. money announcements have the most consistent effects. Becker et al (1995) examine the impact of U.S. and U.K. news on futures prices of U.S., U.K., German and

\footnotetext{
${ }^{2}$ Recently, Becker, Finnerty and Kopecky (1995) have examined cross-country spillover effects on interest rates.

${ }^{3}$ Hogan, Melvin and Roberts (1991) find the same trade balance effect. Irwin (1989) finds a significant break in the relationship between trade balance movements and dollar exchange occurring in June 1984 .
} 
Japanese government bonds. They find that certain U.S. information has a significant influence on German and Japanese interest rates while U.K. information had almost no effect on foreign rates.

This paper makes three contributions to the literature. First, it uses recent data and hence updates findings of earlier studies. Second, it focuses on only two bilateral exchange rates, making it possible to investigate the sensitivity of the initial findings by examining several alternative specifications to the basic equation. In particular, it allows for the possibility of asymmetric responses -- large-and-small errors and positive-and-negative errors -- for changes in response during different phases of monetary policy, and for volatility in the foreign exchange market. Third, it examines how U.S. macroeconomic news affects not only U.S. interest rates, but also how U.S. news affects German and Japanese interest rates.

In general, I find that exchange rates are most likely to react to news about the state of the economy, rather than to inflationary pressures, but that this reaction appears to be extremely small -even though it is statistically significant, it does not appear to be quantitatively significant. ${ }^{4}$ In contrast, U.S. interest rates react to the entire spectrum of news we considered, but once again the effect does not appear to be quantitatively significant. Long- and short-term Japanese interest rates appear to react to U.S. employment news, while German interest rates appear to be unaffected by U.S. news, with the exception of these short-term rates reacting to U.S. inflation surprises in the early 1980s. At that time, German monetary policy was closely linked to U.S. monetary policy and high interest rates, but in 1984, the Germans decoupled their monetary policy from that of the United States.

The remainder of the paper is organized as follows: Section 2 contains a description of the data. Section 3 presents the underlying basic model and reports on the exchange rate results; while section 4 discusses the interest rates results. Section 5 concludes the paper.

\section{Data Description}

\subsection{The expectations data}

The main focus of this paper is to investigate the effects of macroeconomic news on two bilateral exchange rates, the mark/dollar and the yen/dollar. It also examines the response of U.S., German, and Japanese interest rates to these data. The macroeconomic news is associated with the monthly release of data on six U.S. economic variables: consumer price index for urban consumers

\footnotetext{
${ }^{4} \mathrm{~A}$ recent study by Harris and Zabka (1995) also finds a significant and positive link between non-farm payroll surprises and the exchange rate.
} 
(CPI), producer price index for finished goods (PPI), total index of industrial production (IP), growth in nominal retail sales (RS), the unemployment rate (UN), and the change in nonfarm payroll employment (NF). All the variables are announced with a one-month lag and quoted in percentage points and represent month-to-month percentage changes, with the exception of the employment variable (NF), which is quoted in thousands of persons. For example, the CPI release of February 15, 1995 was 0.4 , indicating that the consumer price level rose by 0.4 percent during January. The sample period runs from February 1980 to February 1995.

It is quite difficult to create a good forecast for each of these announcements. Instead, I use the survey data of expectations regarding the value of the variable to be released. The survey data are from Money Market Services (MMS), which is the same source as used by earlier researchers. ${ }^{5}$ MMS conducts a survey of about forty money market managers on the Friday the week before the release of each variable under consideration. The median forecast from the survey is used. ${ }^{6}$ Hence, the news associated with the release of each variable is identified as the difference between the value released and the median of the survey responses. For example, in the survey conducted on February 10, 1995, five days prior to the CPI release of the month, the median expected value of the CPI release was 0.3 percent. The actual release value for the CPI was 0.4 percent, therefore the expectation error or 'news' for the month of February was 0.1 percent.

Table 1 presents the absolute frequency distribution of the expectation errors associated with each of the variables. There are 181 announcements (February 1980 - February 1995) in our sample period for each variable except nonfarm payroll where there are only 121 announcements (February 1985 - February 1995). According to these results, survey participants are more accurate at forecasting CPI than they are at forecasting RS. In over 50 cases ( 28 percent) the expectation error for the CPI was zero, while there were only 9 instances ( 5 percent) when the expectations error was zero for RS. The distributional properties for UN, IP, and PPI lie somewhere between these two variables. Further note that the distributions for PPI, RS, and NF expectation errors tend to be

\footnotetext{
'See for example Engel and Frankel (1984), Hakkio and Pearce (1985), Ito and Roley (1987), Hardouvelis (1988), and Hogan et al (1991).

${ }^{6}$ There is one severe drawback to the methodology I employ, which is a problem in most other studies, and that is the treatment of the median forecast as measure of central tendency. This methodology fails to take account of the individual survey respondents' uncertainty as well as the general diversity of opinions.
} 
slightly skewed to the left (or negative). ${ }^{7}$ However, on average the errors, as shown in Table 2, are not statistically significantly different from zero, the only exception is for PPI.

Table 3 gives the expectation errors associated with the data releases since January 1994. The expectation errors for CPI, RS, UN, and NF do not appear to display any unusual patterns. In contrast, there are two relatively large negative errors for PPI in October and November of 1994. The market appears to have been surprised by rather lower than expected month-to-month changes in producer prices. Furthermore, market participants appeared to have consistently under-estimated the strength of the economy during much of 1994 and early 1995 as there is a long string of positive expectation errors for the IP variable.

To further examine the data, two tests are performed. First, I consider the individual univariate statistical properties of the released and survey data using unit root tests. Table 4 reports these tests using a simple augmented Dickey-Fuller test with one lag. The null hypothesis of this test is that the time series has a unit root. The null is usually rejected; however there are three exceptions: actual unemployment, expected unemployment, and expected nonfarm employment data. Second, I consider how closely related each pair of series are because if the survey data is useful, it should be closely linked to the announced data. Previous authors, see Pearce and Roley (1985) for example, test if the survey data are rational, by testing for a systematic bias. As Granger and Newbold (1986) have pointed out this test has several problems, therefore, I test using a slightly different methodology. I test whether the survey data are cointegrated with the actual released data The results (Table 4, Row: coint) suggest it is possible to reject the null of non-cointegration, indicating that the survey forecasts and the release data move together.

\subsection{Exchange Rates}

The two exchange rates, mark/dollar and yen/dollar are noon rates from the New York market. In the regressions, the dependent variable is 100 times the change in (the log of) the exchange rate between noon the day of the announcement and the preceding noon rate. The factor 100 transforms the units of the dependent variable to percentages. More precisely, the dependent variable is as follows:

\footnotetext{
${ }^{7}$ For PPI, there are 56 announcements where the expectation error is positive and 97 announcements where the errors are negative, excluding all zero values The difference for NF is less pronounced: 63 negative surprises and 48 positive surprises.
} 


$$
\begin{gathered}
-6- \\
\Delta s_{t}=100 *\left(\log s_{t}-\log s_{t-1}\right)
\end{gathered}
$$

where $s_{t}$ denotes the exchange rate. The largest one-day change (February 13, 1981) for the mark is 3.2 percent on a day when there was a PPI announcement with an expectation error of zero. The largest one-day change (January 15, 1988) for the yen was 2.93 percent when PPI and IP were announced with expectational errors of 0.4 and 0.1 .

\subsection{Interest Rates}

Two time horizons for interest rates are used: short-term (three-months) and long-term (10years). For the short-term horizon I use three-month nominal interbank rates for the foreign rates and the three-month Treasury bill rate for the United States. For the long-term horizon, nominal interest rates are yields on 10-year bellwether government bonds for the foreign rates and the yield on a 10year constant maturity Treasury bond for the United States. In the regression, the dependent variable is the change in the interest rate between the noon the day of the announcement and the preceding noon rate.

\section{Patterns in the response of the exchange rate to news}

Charts 1 and 2 illustrate the reaction of each exchange rate to the expectation error for each news variable. Each chart contains six panels using data from the entire sample, February 1980 to February 1995. Each panel displays a scatter diagram showing the daily percent change of the exchange rate on the vertical axis and the expectation error/news on the horizonal axis. In general, the two charts illustrate substantial variations in the reaction of exchange rates to news. For example, the upper leftmost panel for CPI news in chart 1 shows the mark/dollar exchange rate changes in both positive and negative directions. From these charts, it is difficult to discern any systematic relationship. Furthermore, in some months two or more announcements coincide, therefore it is necessary to consider changes in the exchange rate to all news variables simultaneously.

To investigate the effect of news the following equation is estimated:

$$
\Delta s_{t}=\alpha_{0}+\sum_{i=j}^{n} a_{i} x_{i t}^{e}
$$

where $x_{i}^{e}$ is the expectation error of the corresponding economic series at time t. Equation (2) is estimated when all six news variables are considered jointly, thus $\mathrm{j}=1$ and $\mathrm{n}=6$.

Table 5 reports the response of the two exchange rates to news. For each exchange rate, two time periods are estimated: February 1980 to February 1995 and February 1984 to February 1995. The 
latter time period omits the high inflation period of the early 1980s. Each coefficient corresponds to the response of the exchange rate to that news variable. For example, the entry in the CPI column for the mark/dollar for the entire sample period is -0.34 . This coefficient suggests that the reaction to the exchange rate to a $.1 \mathrm{CPI}$ error has been on average -0.03 percent. For Germany, it is quite common to find a negative coefficient on CPI which is consistent with the hypothesis that higher-than-expected inflation leads agents to expect higher future inflation and hence a depreciation of the dollar. For Japan, the coefficient is on CPI is almost always positive and insignificant. Otherwise it is common to find positive coefficients on the other variables with the exception of unemployment (UN). The negative sign on $\mathrm{UN}$ is consistent with the hypothesis that a stronger-than-expected U.S. economy will lead to an appreciation of the dollar.

In general, the responses of the two exchange rates are not statistically significant at or below the 10 percent significance level. The main exception on table 5 is the coefficient on nonfarm payroll employment. The coefficient is statistically significant at the 5 percent level for both the mark and the yen; however, it does not appear to be quantitatively significant. ${ }^{8}$ A surprise of 100,000 nonfarm payroll leads to a 0.2 percent appreciation of the exchange rate. Harris and Zabka (1995) argue that the U.S. employment report tends to move exchange rates -- with the exception of the Canadian dollar where there is no impact -- and that this influence has increase over time.

In the next few subsections, I will examine how sensitive these results are by considering various alternative specifications of equation (2).

\subsection{Reaction to positive and negative errors}

The average reactions presented in Table 5 assume that the reaction of the exchange rate to news about a variable is symmetrical in response to positive or negative errors. Therefore, I allow for the possibility of an asymmetric response. Table 6 contains estimates for positive and negative errors. ${ }^{9}$ One noticeable difference in this table is that there are several entries relating to the level of economic activity that are statistically significant at or below the 10 percent significance level. The coefficients on retail sales become statistically significant when split this way. It is interesting to note the sign

\footnotetext{
${ }^{8}$ The explanatory power of these six variables is low: the adjusted R-square is about 0.005 for both exchange rates. Note that the dependent variable is the change in the log of each exchange rate. The residual diagnostics suggests the residuals are white noise, indicating no obvious misspecification. The general fit of these equations are consistent with those in the literature, see for example Hardouvelis (1988).

${ }^{9}$ The definition of positive errors includes zero. The findings are not altered when positive errors are defined to be all values greater than zero as opposed to greater than or equal to zero.
} 
reversals of the coefficients. When there is a positive surprise the exchange rate responds by depreciating, which is the same response when there is a negative surprise. Consequently, it is not clear how one should interpret these signs. For Germany, the coefficient for UN surprises when there is negative news is statistically significant, and the sign is consistent with theory. These results seem to indicate there might be some persistent reaction of exchange rates to news, but the data must be carefully separated. Further, note that the size of the coefficients remain small, indicating that the effect remains quantitatively small.

\subsection{Response to large and small errors}

Next, I consider whether the response of the dollar depends on the size of the surprise. I define large surprises as those that are above the 90th percentile (positive responses) and those below the 10th percentile (negative responses). Table 7 reports the response of the exchange rate to large and small errors. Interestingly, the responses do not differ between large news and small news, nor do they differ dramatically from the average responses. For example the response for the mark/dollar exchange rate to inflationary news (column CPI) is -0.33 indicating that the exchange rate, on average, will decline by 0.03 percent in response to an 0.1 error for CPI. This response, as before, is not statistically significant. It appears that separating out the response by large and small leads to some increase in significance for IP surprises, but the general result that the response of exchange rates to news remains the same: very small.

\subsection{Recent Behavior}

In February 1994, the Federal Reserve began tightening monetary when it increased the discount rate and the federal funds rate by 25 basis points on February 4th after the employment report. Monetary policy remained tight throughout the rest of my sample period. This section examines whether the response of the dollar from February 1994 - February 1995 has been statistically different from those in earlier periods. Table 8 presents these results. In this table the coefficients reported are those on the multiplicative dummy for the recent time period. To determine the total effect one needs to add these responses to the average response as reported in Table 5. None of the multiplicative dummy coefficients for either currency is significant, suggesting the responses during this period have not been different from those in the earlier periods. Although the dollar has weakened during much of this period there does not appear to be any statistical association with macroeconomic news as I am measuring it.

\subsection{Alternative Specifications}

This section continues to examine the sensitivity of the previous results by considering two 
further modifications: (1) adding a variable to take account of volatility in the foreign exchange market ${ }^{10}$ and (2) dividing the sample into further sub-samples to determine whether the reaction to news changes during different phases of monetary policy. Table 9 contains these results. The first row for each exchange rate reports the coefficients on the news variables for the whole sample when we include the 5-day moving average volatility term (column MAVOL). The inclusion of the moving average term is statistically significant, but the coefficients on the news variables are essentially unchanged.

The last four rows of the table break the sample period into smaller episodes. These subsamples were selected on the basis of the discussion found in Goodfriend (1993), which described the Federal Reserve's monetary policy. The four sub-samples are as follows: February 1980 - October 1982 (Aggressive Disinflationary Policy), November 1982 - April 1986 (Establishing Credibility), May 1986 - June 1990 (Maintaining Credibility) and July 1990 - February 1994 (Recession and Recovery). The results differ across sub-samples. The sign of the coefficients and the significance change. The results in this table suggest that occasionally perhaps there is a relationship between news and the exchange rate, but that it is not stable over time.

\section{Patterns in the response of interest rates to news}

I now turn to examining the relationship between news and interest rates. First, I examine the response of changes in the 3-month U.S. Treasury bill rate and the 10-year U.S. Treasury bond rate to the same economic news. Then, I examine the spillover effects of U.S. news on foreign interest rates. This test enables me to investigate whether there is a link between countries in addition to those, albeit weak, found for exchange rates. Once again, I use two time horizons -- 3-month rates and 10-year -for Germany and Japan.

Charts 3 - 8 plot the reaction of changes in each interest rate to the expectation error for each news variable. These charts are quite similar to the patterns displayed in charts 1 and 2 , except that in general interest rates responses are less volatile. In charts 3 and 4 , it is possible to discern that there might be a small, but positive relationship between U.S. interest rate responses and NF news. This positive relationship is uncovered in our regression analysis.

Table 10 reports the results of estimating equation 2 , replacing daily changes in the interest rate for daily changes in the exchange rate. The most striking result in this table is that both short-

\footnotetext{
${ }^{10} \mathrm{I}$ also estimated these equations where I included the lagged dependent variable. The coefficient and the equation fit was somewhat better, but the interpretation of the news coefficients did not change.
} 
and long-term U.S. interest rates systematically (statistically significant at the 5 percent level) react to all six news variables. This result is consistent with others findings see for example Roley and Troll (1983). Notice, however, that quantitative significance is rather small: a 0.1 surprise on CPI leads to only a 1 basis point increase in either short or long term interest rates.

The lower two thirds of table 10 contains the results of the response of foreign interest rates to U.S. news. Overall, German interest rates do not tend to react to news on U.S. macroeconomic variables. The data for the entire period reveals that German short-term interest rates react systematically to U.S. inflationary news. This positive relationship stems from an early association of German monetary policy to U.S. inflation and hence U.S. monetary policy. German monetary policy was decoupled from U.S monetary policy in early 1984 and hence the lack of significance in the period since then. In contrast, I find a very small negative, but significant relationship between Japanese short-term interest rates and U.S. nonfarm payroll employment surprises and unemployment rate surprises. Otherwise, it appears that U.S. news has little impact on Japanese interest rates. As there is very little reaction of foreign interest rates to U.S. news I do entertain further tests to test how news is transmitted.

\section{Conclusion}

This paper investigates the short-run reaction of exchange rates and interest rates to U.S. macroeconomic news when news is associated with the surprise component of the monthly release of U.S. macroeconomic variables. Survey data on market participants' expectations of these announcements are used to form the news on these variables. This paper does not address the extent to which gradual changes in market participants perceptions/expectations are priced into exchange rates. The main conclusion that emerges from the empirical results is that exchange rates are more likely to react to news about the state of the economy, rather than about past inflation, but that this reaction appears to be extremely small -- even though it is statistically significant it does not appear to be quantitatively significant. In contrast, U.S. interest rates systematically react to the entire spectrum of news, but then these effects do not appear to be quantitatively significant. Long- and short-term Japanese interest rates appear to react to employment news, while German interest rates appear to be unaffected by U.S. news, with the exception of German short-term rates reacting to U.S. inflation surprises in the early 1980 s. 


\section{References}

Becker, Kent G., Joseph E. Finnerty, and Kenneth J. Kopecky, 1995, "Domestic Macroeconomic News and Foreign Interest Rates," Journal of International Money and Finance, December, 14: 763-783.

Dornbusch, Rudiger, 1980, "Exchange Rate Economics: Where Do We Stand?" Brookings Papers on Economic Activity, 143-94.

Edwards, Sebastian, 1982, "Floating Exchange Rates, Expectations and New Information," Journal of Monetary Economics, 11: 321-336.

Engel, Charles and Jeffrey A. Frankel, 1984, "Why Interest Rates React to Money Announcements: An Explanation from the Foreign Exchange Market," Journal of Monetary Economics, 13: 31-39.

Frankel, Jeffrey A. and Andrew K. Rose, 1995, "A Survey of Empirical Research on Nominal Exchange Rates," in The Handbook of International Economics eds. Gene Grossman and Kenneth Rogoff.

Frenkel, Jacob, 1981, "Flexible Exchange Rates, Prices and the Role of 'News'," Journal of Political Economy, 70:2 (May) 235-42.

Ghosh, Sucharita and Donald Lien, 1995, "Data Revision and Market Response: The Case of United States Trade Balance Announcements," Oxford Bulletin of Economics and Statistics, 57: 265-275.

Goodfriend, Marvin, 1993, "Interest Rate Policy and the Inflation Scare Problem: 1979 - 1992," Federal Reserve Bank of Richmond Economic Quarterly, Winter, 1 - 24.

Granger, Clive W. J. and Paul Newbold, 1986, Forecasting Economic Time Series, New York: Academic Press.

Hakkio, Craig S. and Douglas K. Pearce, 1985, "The Reaction of Exchange Rates to Economic News," Economic Inquiry, 23: 621-636.

Hardouvelis, Gikas, 1988, "Economic News, Exchange Rates and Interest Rates," Journal Of International Money and Finance, March: 7, 23 - 36.

Hogan, Ked, Michael Melvin, and Dan J. Roberts, 1991, "Trade Balance News and Exchange Rates: Is There a Policy Signal?" Journal Of International Money and Finance, March: 10, S90-S99.

Harris, Ethan S. and Natasha M. Zabka, 1995, "The Employment Report and the Dollar," Current Issues in Economics and Finance, Federal Reserve Bank of New York, Vol 1, No 8, November, 1-6.

Husted, Steven and John Kitchen, 1985, "Some Evidence on the International Transmission of U.S. Money Supply Announcement Effects," Journal of Money, Credit and Banking, November, 17: 456466.

Irwin, Douglas A., 1989, "Trade Deficit Announcements, Intervention and the Dollar," Economic Letters, December 31: 257-262. 
Ito, Takatoshi and V. Vance Roley, 1987, "News from the U.S. and Japan: Which Moves the Yen/Dollar Exchange Rate?" Journal of Monetary Economics, 19: 255-277.

Klein, Michael, Bruce Mizrach and Robert G. Murphy, 1991, "Managing the Dollar: Has the Plaza Agreement Mattered?" Journal of Money, Credit and Banking, November, 23: 742-751.

Orphanides, Athanasios, 1992, "On the Reaction of Interest Rates to Economic News," Federal Reserve Board, unpublished memo.

Pearce, Douglas K. and V. Vance Roley, 1985, "Stock Prices and Economic News," Journal of Business, 58: 49-67.

Roley, V. Vance and Rick Troll, 1983, "The Impact of New Economic Information on the Volatility of Short-Term Interest Rates," Economic Review, Federal Reserve Bank of Kansas City, February, 315.

Rose, Andrew K., 1984, "Testing for 'News' in Foreign Exchange Markets," Economic Letters, 14: 369-376.

Urich, T. and P. Wachtel, 1984, "The Effects of Inflation and Money Supply Announcements on Interest Rates," Journal of Finance, September 39: 1177- 1188. 


\begin{tabular}{|c|c|c|c|c|c|c|c|c|c|}
\hline \multicolumn{10}{|c|}{$\begin{array}{l}\text { Table } 1 \\
\text { Absolute Frequency Distributions of Expectation Errors (181 observations) }\end{array}$} \\
\hline \multirow[t]{2}{*}{ Variable } & \multicolumn{9}{|c|}{ Error Size (percentage points) } \\
\hline & $<-0.3$ & -0.3 & -0.2 & -0.1 & 0 & +0.1 & +0.2 & +0.3 & $>+0.3$ \\
\hline CPI & 4 & 5 & 16 & 40 & 53 & 36 & 18 & 6 & 3 \\
\hline PPI & 30 & 21 & 20 & 26 & 28 & 20 & 14 & 8 & 14 \\
\hline IP & 20 & 14 & 21 & 22 & 26 & 32 & 24 & 5 & 17 \\
\hline RS & 59 & 6 & 13 & 15 & 9 & 10 & 8 & 11 & 50 \\
\hline \multirow[t]{3}{*}{ UN } & 6 & 6 & 32 & 38 & 42 & 28 & 17 & 8 & 4 \\
\hline & \multicolumn{9}{|c|}{ Error Size (thousands of persons) ${ }^{2}$} \\
\hline & $<-100$ & -100 & -50 & -10 & 0 & 10 & 50 & 100 & $>100$ \\
\hline NF & 20 & 20 & 19 & 4 & 0 & 4 & 13 & 20 & 21 \\
\hline
\end{tabular}

Notes: Expectations errors are the difference between the announced value and the median of the survey responses.

$\mathrm{CPI}$ : The consumer price index for all urban consumers.

PPI: The producer price index for finished goods.

IP: The total index of industrial production.

RS: The nominal value of retail sales.

UN: The unemployment rate.

NF: The non-farm payroll employment.

1. Sample Period: February 1980 - February 1995.

2. Sample Period: February 1985 - February 1995. 


\begin{tabular}{||l|l|l||}
\hline \multicolumn{3}{|c|}{ Descriptive Statistics of Expectation Errors } \\
\hline Variable & Mean & t-statistic \\
\hline CPI & -0.0005 & -0.046 \\
\hline PPI & -0.082 & $-3.61^{\circ}$ \\
\hline IP & -0.0116 & -0.48 \\
\hline RS & -0.040 & -0.67 \\
\hline UN & 0.954 & 1.76 \\
\hline NF & 3.52 & 0.32 \\
\hline
\end{tabular}

CPI: The consumer price index for all urban consumers.

PPI: The producer price index for finished goods.

IP: The total index of industrial production.

RS: The nominal value of retail sales.

UN: The unemployment rate.

NF: The non-farm payroll employment.

1. Sample Period: February 1980 - February 1995.

2. Sample Period: February 1985 - February 1995. 
$-15-$

\begin{tabular}{|c|c|c|c|c|c|c|}
\hline \multicolumn{7}{|c|}{$\begin{array}{c}\text { Table } 3 \\
\text { Expectation Errors since January } 1994 \text { (percentage points) }\end{array}$} \\
\hline \multirow[t]{2}{*}{ Date } & \multicolumn{6}{|c|}{ Variable } \\
\hline & CPI & PPI & IP & RS & UN & $\mathrm{NF}$ \\
\hline Jan. 1994 & -0.2 & 0.0 & 0.3 & 0.4 & -0.1 & -32 \\
\hline Feb. 1994 & 0.0 & -0.2 & 0.1 & -0.8 . & -0.2 & -153 \\
\hline Mar. 1994 & 0.0 & 0.2 & 0.2 & 1.0 & -0.2 & 67 \\
\hline Apr. 1994 & 0.0 & 0.0 & -0.2 & -0.6 & 0.0 & 226 \\
\hline May 1994 & -0.1 & -0.3 & 0.0 & 0.5 & -0.1 & 92 \\
\hline Jun. 1994 & -0.2 & -0.3 & 0.1 & -0.2 & -0.4 & -84 \\
\hline Jul. 1994 & 0.0 & -0.3 & 0.4 & 0.1 & -0.2 & 137 \\
\hline Aug. 1994 & 0.0 & 0.2 & 0.1 & -0.5 & 0.0 & 49 \\
\hline Sep. 1994 & 0.0 & 0.2 & 0.2 & -0.2 & 0.0 & -54 \\
\hline Oct. 1994 & 0.1 & -0.7 & -0.3 & 0.2 & -0.2 & -9 \\
\hline Nov. 1994 & -0.1 & -0.6 & 0.2 & 0.4 & -0.1 & -51 \\
\hline Dec. 1994 & -0.2 & 0.1 & 0.0 & 0.7 & -0.2 & 100 \\
\hline Jan. 1995 & -0.3 & 0.0 & 0.4 & -0.8 & -0.2 & -4 \\
\hline Feb. 1995 & 0.1 & -0.1 & 0.0 & -0.2 & 0.3 & -91 \\
\hline
\end{tabular}

Notes:

1. Numbers are thousands of persons. 


\begin{tabular}{|c|c|c|c|c|c|c|}
\hline \multicolumn{7}{|c|}{$\begin{array}{c}\text { Table } 4 \\
\text { Unit Root Tests } \\
\text { February } 1980-\text { February } 1995\end{array}$} \\
\hline \multirow[t]{2}{*}{ Type } & \multicolumn{6}{|c|}{ Variable (t-statistic) } \\
\hline & CPI & PPI & IP & RS & UN & $N F^{\prime}$ \\
\hline Released & $-6.0^{\circ}$ & $-8.1^{\circ}$ & $-5.2^{\circ}$ & $-13.2^{\circ}$ & -1.25 & $-3.58^{\circ}$ \\
\hline Expected & $-5.5^{\circ}$ & $-6.1^{\circ}$ & $-4.6^{\circ}$ & $-12.2^{\circ}$ & -1.14 & -2.24 \\
\hline Coint Test & $-15.0^{\circ}$ & $-12.1^{\circ}$ & $-11.5^{\circ}$ & $-16.6^{\circ}$ & $-12.2^{\circ}$ & $-11.40^{\circ}$ \\
\hline
\end{tabular}

Row 1 (Released) unit root test on the actual release data.

Row 2 (Expected) unit root test on the survey data.

Row 3 reports a Engle-Granger two step cointegration test between the released and the expected variable.

The unit root test applied is an augmented Dickey-Fuller test with one lag.

* denotes significant at 5 percent level. 


\begin{tabular}{|c|c|c|c|c|c|c|}
\hline \multicolumn{7}{|c|}{$\begin{array}{l}\text { Table } 5 \\
\text { Average Response Rate of Mark/Dollar and Yen/Dollar Exchange Rates to News (percent) }\end{array}$} \\
\hline \multirow[t]{2}{*}{ Rate/Period } & \multicolumn{6}{|c|}{ News Variable } \\
\hline & CPI & PPI & IP & RS & UN & NF \\
\hline \multicolumn{7}{|l|}{$\mathrm{DM} / \$$} \\
\hline Feb. 80 - Feb 95 & -0.34 & 0.07 & 0.24 & 0.04 & $-0.49^{\prime \prime}$ & $0.002^{\circ}$ \\
\hline Feb. 84 - Feb 95 & -0.77 & 0.07 & 0.33 & 0.07 & -0.51 & $0.002^{\circ}$ \\
\hline \multicolumn{7}{|l|}{ Yen/\$ } \\
\hline Feb. 80 - Feb 95 & 0.26 & 0.13 & -0.4 & 0.00 & -0.27 & $0.002^{\circ}$ \\
\hline Feb. 84 - Feb 95 & -0.21 & 0.17 & 0.02 & 0.03 & -0.4 & $0.002^{\circ}$ \\
\hline
\end{tabular}

Notes: There are 181 announcements (February 1980 to February 1995) for each variable except nonfarm payroll where there are only 121 announcements (February 1985 - February 1995). The result are based on the following estimated equation:

$$
\Delta s_{t}=\alpha_{0}+\sum_{i=j}^{n} a_{i}\left(x_{i t}-x_{i t}^{e}\right)
$$

where:

$\Delta s_{1}$ denotes the change in the log of the exchange rate during the release day,

$x_{i 1}$ denotes actual release data at time $t$ and $i$ corresponds to CPI, PPI, IP, RS, UN, and NF respectively,

$\mathbf{x}_{i 1}^{e}$ denotes market expectations -- measured using survey data from Money Market Services -- on the corresponding variable.

The equation is estimated using all news variables -- hence the summation -- to account for the possibility of simultaneous announcements.

The following symbols * and \# indicate significant at the 5 and 10 percent level. 


\begin{tabular}{||l|l|l|l|l|l|l|l|l|l|l|l||}
\hline \multicolumn{8}{|c|}{ Average Response Rate of Mark/Dollar and Yen/Dollar Exchange Rates to } \\
Positive and Negative Errors (percent)
\end{tabular}

Notes: The estimated equation is based on the following regression:

$$
\Delta s_{t}=\alpha_{0}+\sum_{i=j}^{n} \alpha_{i} D_{P}\left(x_{i t}-x_{i t}^{e}\right)+\sum_{i=j}^{n} \beta_{i} D_{N}\left(x_{i t}-x_{i t}^{e}\right)
$$

where
$\Delta s_{1}$ denotes the change in the exchange rate during the release day
$x_{i t}$ denotes actual release data at time $t$ and $i$ corresponds to CPI, PPI, IP, RS, UN, and NF respectively,
$\mathbf{x}^{\mathrm{e}}{ }_{\mathrm{i}}$ denotes market expectations -- measured using survey data from Money Market Services -- on the corresponding variable.
$D_{p}$, and $D_{n}$ denote positive and negative dummies, respectively.

The following symbols * and \# indicate significant at the 5 and 10 percent level. 


\begin{tabular}{|c|c|c|c|c|c|c|c|c|c|c|c|c|}
\hline \multicolumn{13}{|c|}{$\begin{array}{c}\text { Table } 7 \\
\text { Average Response Rate of Mark/Dollar and Yen/Dollar Exchange Rates to } \\
\text { Large and Small Errors (percent) }\end{array}$} \\
\hline & \multicolumn{2}{|c|}{ CPI } & \multicolumn{2}{|c|}{ PPI } & \multicolumn{2}{|c|}{ IP } & \multicolumn{2}{|c|}{ RS } & \multicolumn{2}{|c|}{ UN } & \multicolumn{2}{|c|}{$\mathrm{NF}$} \\
\hline & Small & Large & Small & Large & Small & Large & Small & Large & Small & Large & Small & Large \\
\hline \multicolumn{13}{|l|}{$\mathrm{DM} / \mathrm{s}$} \\
\hline Feb $80:$ Feb 95 & -0.33 & -0.33 & -0.09 & 0.15 & $0.64^{\circ}$ & 0.94 & -0.11 & 0.04 & 1.07 & -0.58 & -0.003 & $0.002^{\circ}$ \\
\hline Feb 84 - Feb 95 & -0.43 & -0.84 & -0.11 & 0.19 & $0.69^{\prime \prime}$ & 0.13 & -0.61 & 0.08 & 1.53 & $-0.67^{\prime \prime}$ & -0.003 & $0.002^{\circ}$ \\
\hline \multicolumn{13}{|l|}{ Yen/\$ } \\
\hline Feb 80 - Feb 95 & -0.38 & 0.39 & 0.24 & 0.33 & 0.36 & -0.19 & -0.15 & 0.006 & 1.85 & -0.40 & -.004 & $0.002^{\circ}$ \\
\hline Feb 84 - Feb 95 & -1.41 & 0.15 & -0.36 & 0.51 & 0.35 & -0.126 & -0.58 & 0.04 & 1.66 & -0.56 & -.004 & $0.002^{\circ}$ \\
\hline
\end{tabular}

Notes: The estimated equation is based on the following regression:

$$
\Delta s_{t}=\alpha_{0}+\sum_{i=j}^{n} \alpha_{i} D_{L}\left(x_{i t}-x_{i t}^{e}\right)+\sum_{i=j}^{n} \beta_{i} D_{s}\left(x_{i t}-x_{i t}^{e}\right)
$$

where:
$\Delta s_{1}$ denotes the change in the exchange rate (the release day less the previous day)
$x_{\mathrm{it}}$ denotes actual release data at time $t$ and i corresponds to CPI, PPI, IP, RS, UN, and NF respectively,
$\mathbf{x}^{\mathrm{e}}{ }_{\mathrm{it}}$ denotes market expectations -- measured using survey data from Money Market Services - on the corresponding variable.
$D_{s}$ and $D_{1}$ denote small and large dummies, respectively.

The following symbols * and \# indicate significant at the 5 and 10 percent level. 


\begin{tabular}{|c|c|c|c|c|c|c|}
\hline \multicolumn{7}{|c|}{$\begin{array}{c}\text { Table } 8 \\
\text { Average Response Rate of Mark/Dollar and Yen/Dollar Exchange Rates to Recent News (percent) } \\
\text { February } 1994 \text { - February } 1995\end{array}$} \\
\hline \multirow[t]{2}{*}{ Sample Period } & \multicolumn{6}{|c|}{ News Variable } \\
\hline & CPI & PPI & IP & RS & UN & NF \\
\hline \multicolumn{7}{|l|}{$\mathrm{DM} / \mathrm{S}$} \\
\hline Feb. 80 - Feb 95 & 0.04 & 0.11 & 0.06 & -0.25 & -0.97 & 0.001 \\
\hline Feb. 84 - Feb 95 & 0.45 & 0.09 & -0.01 & -0.29 & -1.03 & 0.001 \\
\hline \multicolumn{7}{|l|}{ Yen/\$ } \\
\hline Feb 80 - Feb 95 & -0.13 & 0.25 & 0.70 & 0.06 & $-1.53^{\prime \prime}$ & 0.002 \\
\hline Feb 84 - Feb 95 & 0.35 & 0.21 & 0.67 & 0.03 & $-1.56^{\prime \prime}$ & 0.002 \\
\hline
\end{tabular}

Notes: The entries are on the dummy coefficient $D_{\text {now }}$. The estimated equation is based on the following regression:

$$
\Delta s_{t}=\alpha_{0}+\sum_{i=1}^{4} \alpha_{i}\left(x_{i t}-x_{i t}^{e}\right)+\sum_{i=1}^{4} \beta_{i} D_{n o w}\left(x_{i t}-x_{i t}^{e}\right)
$$

where

$\Delta s_{1}$ denotes the change in the exchange rate during the release day

$x_{i t}$ denotes actual release data at time $t$ and $i$ corresponds to CPI, PPI, IP, RS, UN, and NF respectively,

$\mathbf{x}^{e}{ }_{\text {i1 }}$ denotes market expectations -- measured using survey data from Money Market Services - on the corresponding variable.

$D_{\text {now }}$ denote recent dummy.

The following symbols * and \# indicate significant at the 5 and 10 percent level. 


\begin{tabular}{|c|c|c|c|c|c|c|c|}
\hline \multicolumn{8}{|c|}{$\begin{array}{l}\text { Table } 9 \\
\text { Alternative Specification and Sample Sizes (percent) }\end{array}$} \\
\hline \multirow[t]{2}{*}{ Sample Period } & \multicolumn{7}{|c|}{ News Variable } \\
\hline & $\mathrm{CPI}$ & PPI & IP & RS & UN & NF & Mavol' $^{\prime}$ \\
\hline \multicolumn{8}{|l|}{$\mathrm{DM} / \mathrm{s}$} \\
\hline Feb. 80 - Feb 95" & -0.35 & 0.06 & 0.23 & 0.04 & -0.5 & $0.002^{\circ}$ & $-0.04^{\prime \prime}$ \\
\hline Feb. 80 - Oct 82 & -0.0 & 0.07 & 0.23 & -0.02 & -0.23 & na & - \\
\hline Nov 82 - Apr 86 & $-1.9^{\circ}$ & 0.4 & 0.18 & $0.21^{+}$ & -0.87 & 0.001 & - \\
\hline May 86 - Jun 90 & 0.14 & -0.49 & 0.34 & $-0.26^{\circ}$ & -1.05 & $0.002^{\circ}$ & -- \\
\hline Jul 90 - Feb 94 & -0.19 & 0.04 & 0.13 & $0.59^{\circ}$ & 0.49 & $0.003^{\circ}$ & -- \\
\hline \multicolumn{8}{|l|}{ Yen/\$ } \\
\hline Feb. 80 - Feb 95" & 0.25 & 0.12 & -0.05 & 0.001 & -0.28 & $0.002^{\circ}$ & $-0.09^{\circ}$ \\
\hline Feb. 80 - Oct 82 & 0.53 & 0.21 & -0.03 & -0.004 & 0.41 & na & -- \\
\hline Nov 82 - Apr 86 & 0.12 & 0.33 & 0.09 & 0.09 & $-0.82^{\prime \prime}$ & 0.001 & -- \\
\hline May 86 - Jun 90 & -0.03 & -0.21 & 0.08 & -0.17 & -0.78 & 0.0001 & - \\
\hline Jul 90 - Feb 94 & -0.02 & -0.12 & -0.54 & 0.05 & 0.69 & $0.003^{\circ}$ & -- \\
\hline
\end{tabular}

Notes: Mavol denotes moving average volatility. ${ }^{\text {the }}$ first row in this table includes a variable to represent exchange rate volatility, calculated as the 5 day moving average of squared percent changes in the exchange rate. The other rows report coefficients from the standard equation, dividing the sample as column 1 indicates. The following symbols * and \# indicate significant at the 5 and 10 percent level. 


\begin{tabular}{|c|c|c|c|c|c|c|}
\hline \multicolumn{7}{|c|}{$\begin{array}{l}\text { Table } 10 \\
\text { Average Response Rate of Various Interest Rates to News }\end{array}$} \\
\hline \multirow[t]{2}{*}{ Rate/Period } & \multicolumn{6}{|c|}{ News Variable } \\
\hline & CPI & PPI & IP & RS & UN & $\mathrm{NF}$ \\
\hline \multicolumn{7}{|l|}{ U.S 3-Month } \\
\hline Feb. 80 - Feb 95 & $0.11^{\prime \prime}$ & $0.07^{\circ}$ & $0.06^{\prime \prime}$ & $0.04^{\circ}$ & $-0.18^{\circ}$ & $0.0005^{\circ}$ \\
\hline Feb. 84 - Feb 95 & $0.06^{\prime \prime}$ & $0.05^{\circ}$ & $0.07^{\prime \prime}$ & $0.03^{\circ}$ & $-0.12^{\circ}$ & $0.0005^{\circ}$ \\
\hline \multicolumn{7}{|l|}{ U.S. 10-year } \\
\hline Feb. 80 - Feb 95 & $0.14^{\circ}$ & $0.09^{\circ}$ & $0.05^{\circ}$ & $0.04^{+}$ & $-0.12^{\circ}$ & $0.0004^{\circ}$ \\
\hline Feb. 84 - Feb 95 & $0.11^{\circ}$ & $0.06^{\circ}$ & $0.03^{\circ}$ & $0.03^{+}$ & $-0.11^{\circ}$ & $0.0004^{\circ}$ \\
\hline \multicolumn{7}{|l|}{ German 3-Month } \\
\hline Feb. 80 - Feb 95 & $-0.28^{\circ}$ & -0.01 & 0.001 & 0.01 & -0.005 & -0.000 \\
\hline Feb. 84 - Feb 95 & -0.04 & -0.02 & -0.01 & 0.01 & -0.005 & -0.000 \\
\hline \multicolumn{7}{|l|}{ German 10-year } \\
\hline Feb. 80 - Feb 95 & -0.00 & 0.01 & 0.002 & 0.008 & -0.02 & 0.000 \\
\hline Feb. 84 - Feb 95 & -0.002 & 0.01 & 0.003 & 0.003 & -0.01 & 0.000 \\
\hline \multicolumn{7}{|l|}{ Japanese 3-month } \\
\hline Feb. 80 - Feb 95 & 0.01 & 0.002 & 0.001 & -0.001 & $-0.03^{\circ}$ & $-0.00005^{\circ}$ \\
\hline Feb. 84 - Feb 95 & 0.01 & 0.004 & -0.002 & -0.001 & $-0.03^{\circ}$ & $-0.00005^{\circ}$ \\
\hline \multicolumn{7}{|l|}{ Japanese 10-year } \\
\hline Feb. 80 - Feb 95 & -0.03 & 0.01 & -0.01 & 0.01 & 0.00 & -0.000 \\
\hline Feb. 84 - Feb 95 & -0.04 & 0.01 & -0.01 & 0.08 & 0.004 & -0.0001 \\
\hline
\end{tabular}

Notes: The estimated equation is based on the following regression:

$$
\Delta r_{t}=\alpha_{0}+\sum_{i=1}^{n} \alpha_{i}\left(x_{i t}-x_{i t}^{e}\right)
$$

where

$\Delta r$ denotes the change in the interest rate during the release day

$x_{i t}$ denotes actual release data at time $t$ and $i$ corresponds to CPI, PPI, IP, RS, UN, and NF respectively,

$\mathbf{x}_{\mathrm{it}}^{\mathrm{e}}$ denotes market expectations -- measured using survey data from Money Market Services -- on the corresponding variable.

The following symbols * and \# indicate significant at the 5 and 10 percent level. 


\section{Data Appendix}

Exchange Rates

$\mathrm{DM} / \$$ :

Yen/\$:

\section{Interest Rates}

U.S. Short Term:

U.S. Long Term:

German Short Term:

German Long Term:

Japanese Short Term:

Japanese Long Term:
Mark/dollar exchange rate, Source FRB Bulletin

Yen/dollar exchange rate, Source FRB Bulletin.

\section{Schedule Release Data}

CPI:

PPI:

3-month Tbill rate secondary market, Source: FRB Bulletin 10-year yield on Treasury Bonds, Source: FRB Bulletin 3-month interbank loan rate, Source: Bundesbank

IP:

Combination of authority bonds and Bellwether bond yields, Source Bundesbank.

3-month gensaki rate, Tokyo market, Source Bank of Japan

Long term government bellwether, Source: Bank of Japan

RS:

UN:

NF:

Consumer Price Index, Source: BLS

Producer Price Index, Source BLS

Industrial Production, Source: FRB

Retail Sales (percentage change), Source: Bureau of Census

Unemployment Rate, Source BLS

Nonfarm payroll employment change (thousands of persons), Source: BLS

\section{Survey Data}

Source: Money Market Services.

Data on exchange rates and interest rates are all daily data. Missing data points are filled in with the previous day's values. Most data cover period February 1980 to February 1995. 
DM/\$ Exchange Rate Reaction to News

February 1980 to February 1995
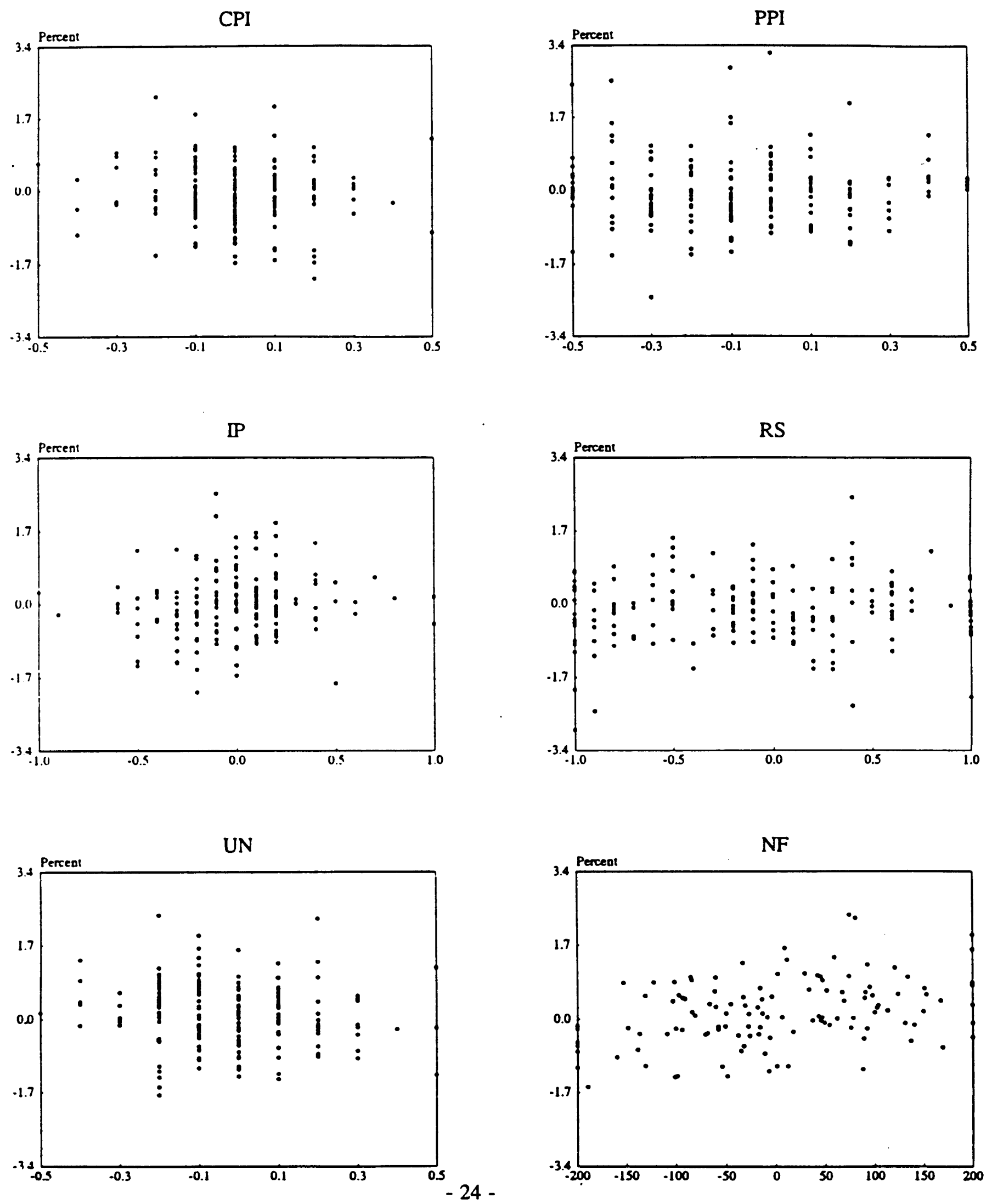
CHART 2

YEN/\$ Exchange Rate Reaction to News

February 1980 to February 1995
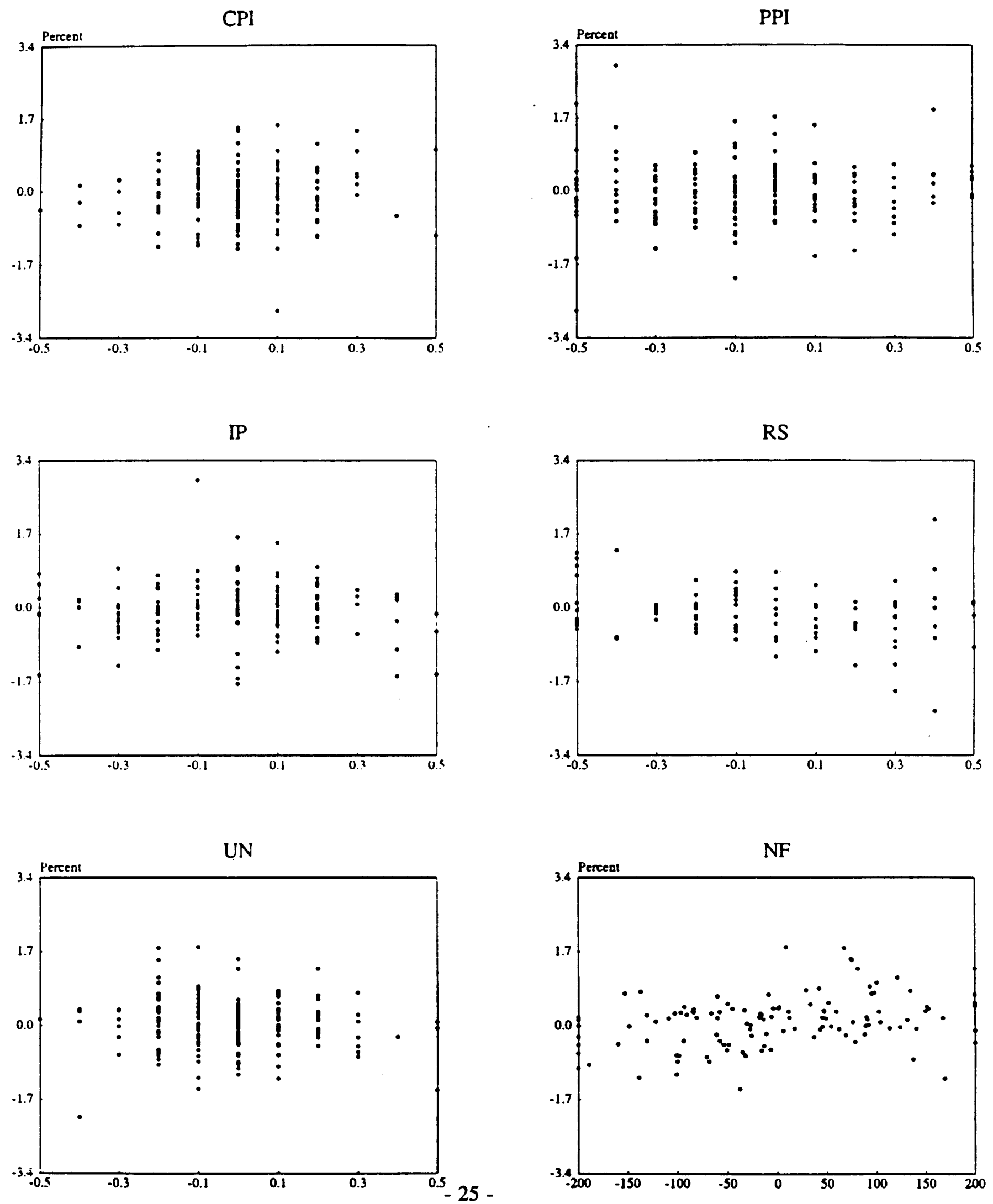


\section{CHART 3}

\section{US 3-Month Interest Rate Reaction to News}

February 1980 to February 1995
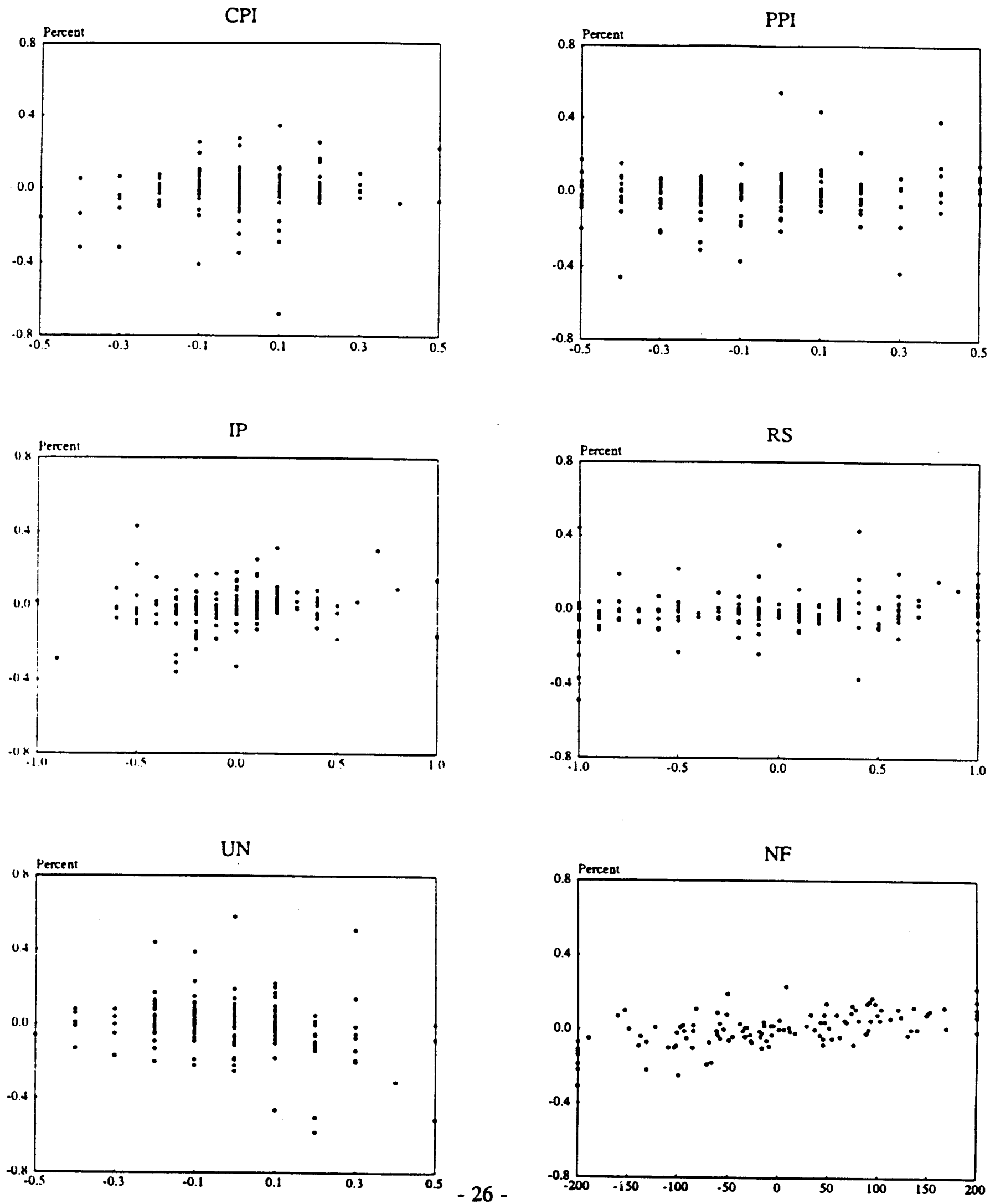


\section{US 10-Year Interest Rate Reaction to News}

February 1980 to February 1995
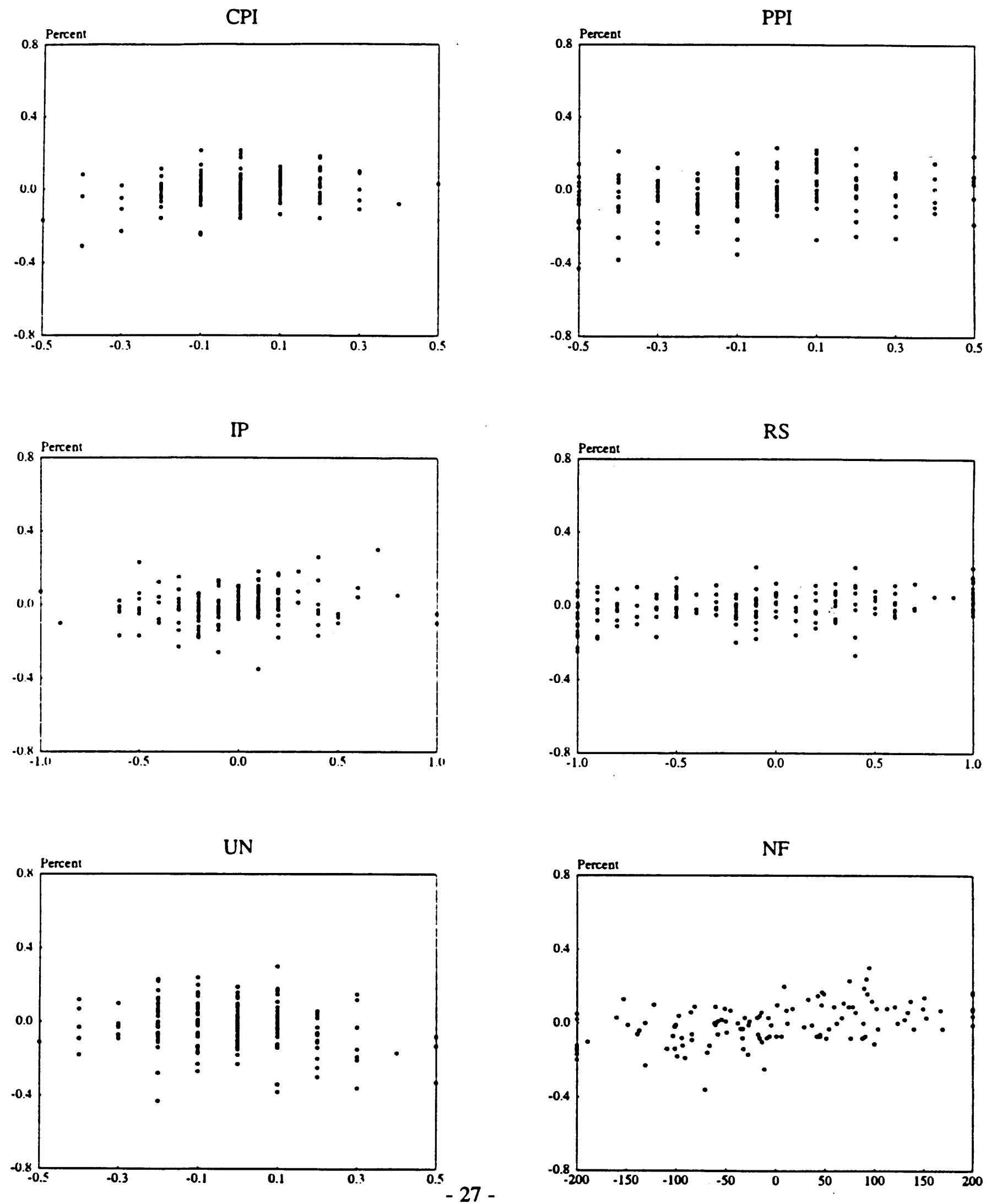


\section{CHART 5}

German 3-Month Interest Rate Reaction to News

February 1980 to February 1995
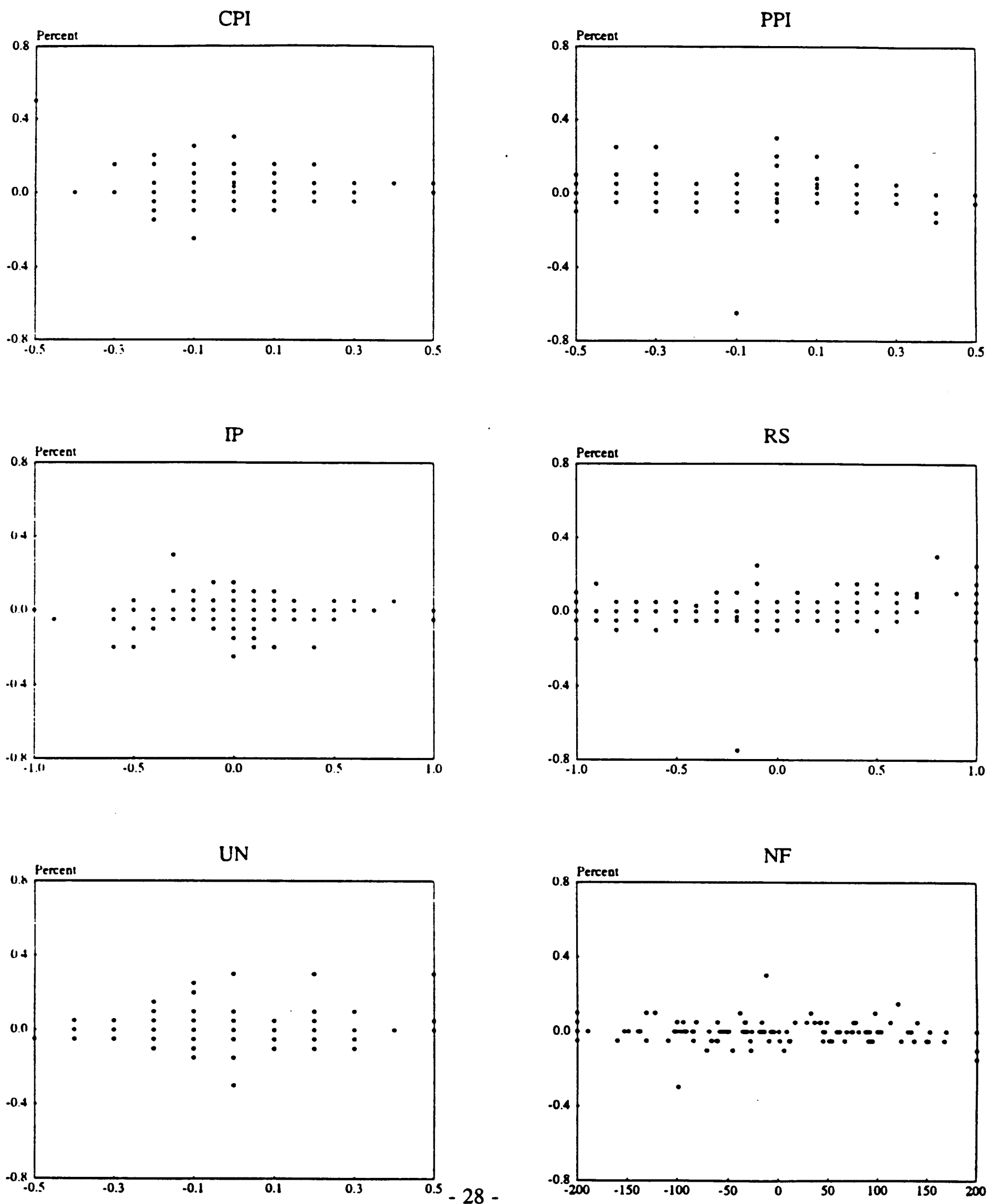


\section{CHART 6}

German 10-Year Interest Rate Reaction to News

February 1980 to February 1995
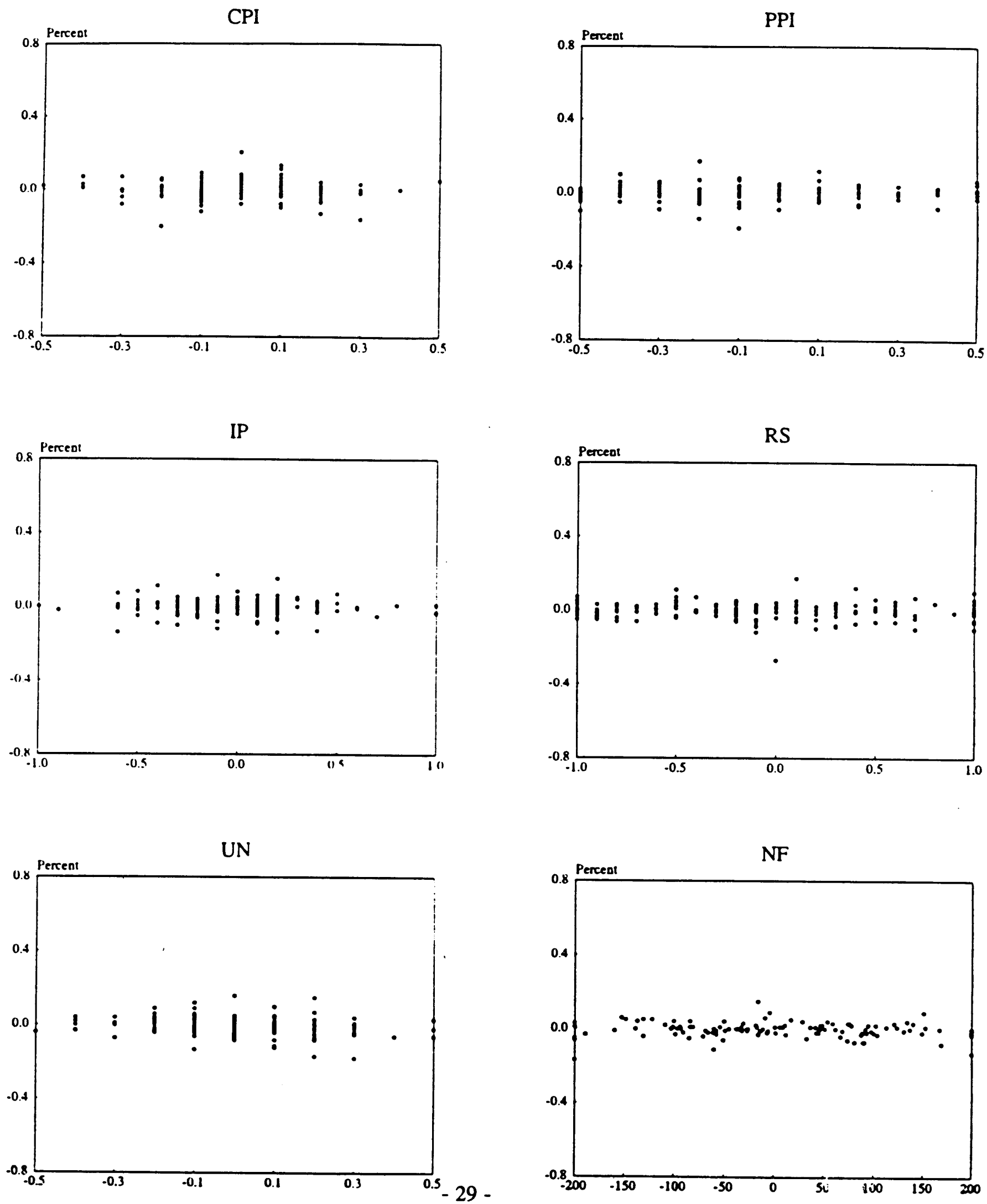


\section{CHART 7}

Japanese 3-Month Interest Rate Reaction to News

February 1980 to February 1995
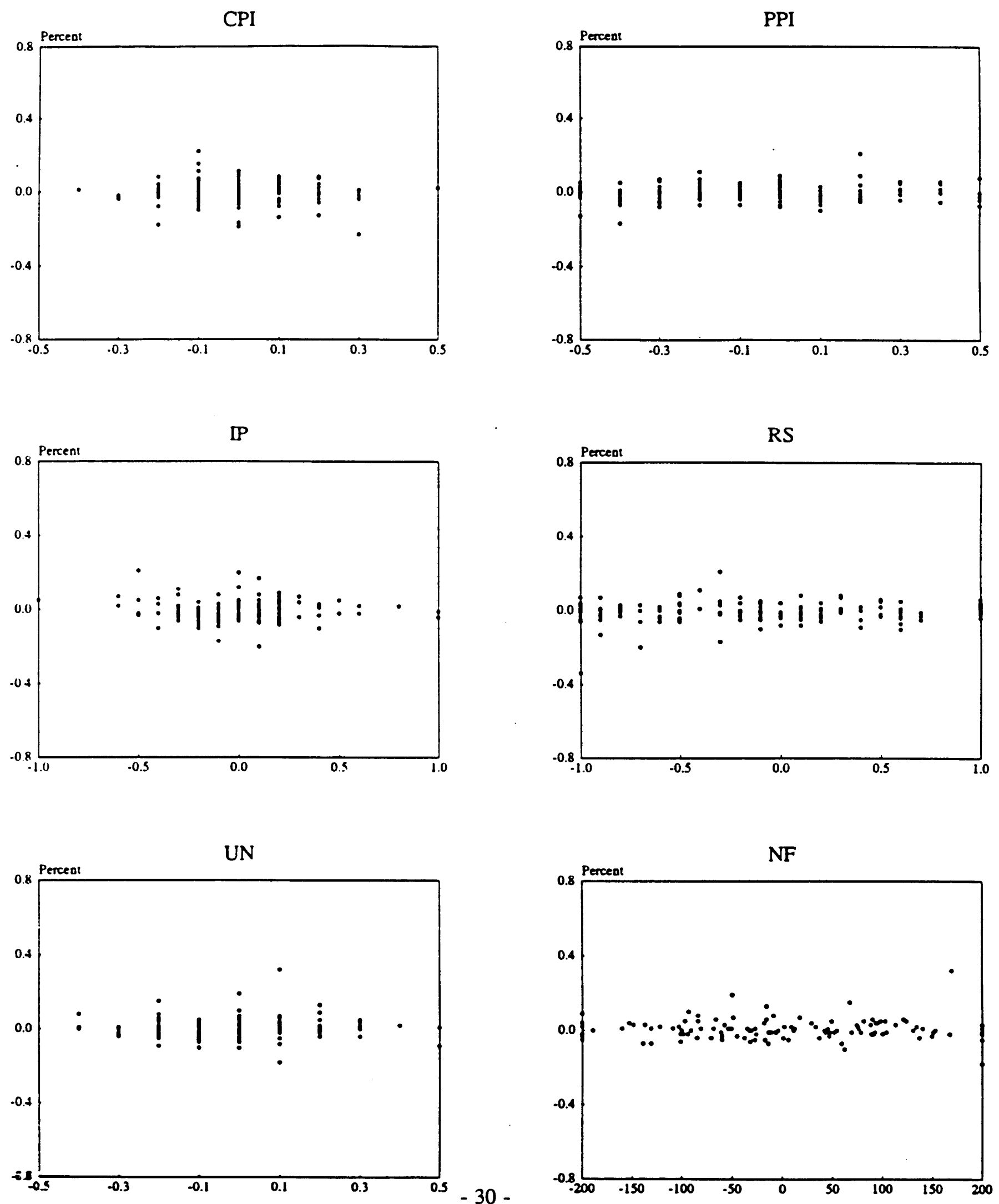


\section{CHART 8}

Japanese 10-Year Interest Rate Reaction to News

February 1980 to February 1995
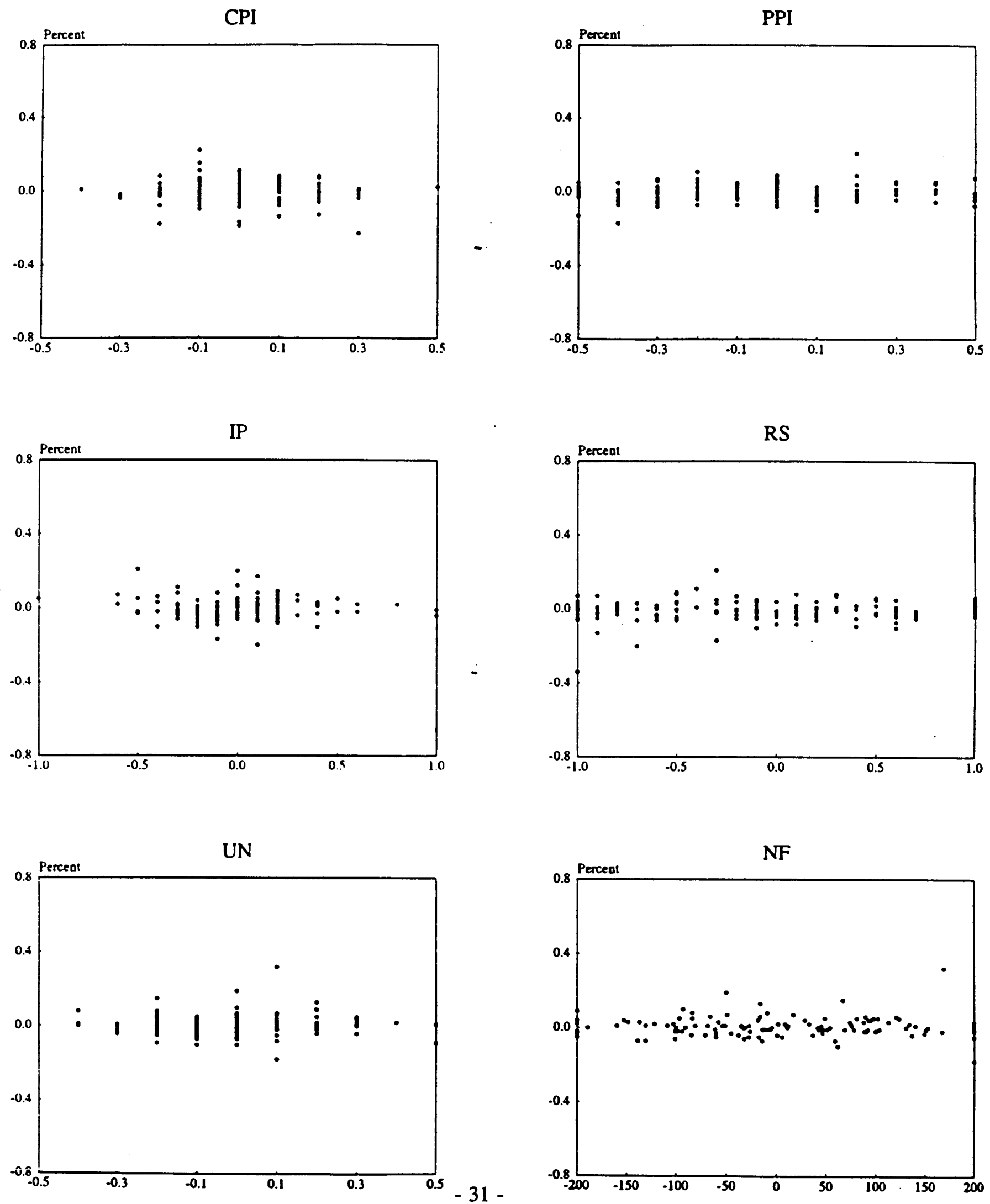


\section{International Finance Discussion Papers}

IFDP

Number $\underline{\text { Titles }}$

$\underline{1996}$

570 The Reaction of Exchange Rates and Interest Rates to News Releases

569 The Role of Credit in Post-Stabilization Consumption Booms
Hazards in Implementing a Monetary Conditions Index

\section{Financial Innovation And The Speed of Adjustment} of Money Demand: Evidence From Bolivia, Israel, And Venezuela

\section{Long-Term Evidence on the Tobin and Fisher} Effects: A New Approach

Some Evidence on the Efficacy of the UK Inflation Targeting Regime: An Out-of-Sample Forecast Approach

The Use of the Parallel Market Rate as a Guide to Setting the Official Exchange Rate

Country Fund Discounts and the Mexican Crisis of December 1994: Did Local Residents Turn Pessimistic Before International Investors?

Eastern European Export Performance during the Transition

Inflation-Adjusted Potential Output

The Management of Financial Risks at German Nonfinancial Firms: The Case of Metallgesellschaft

Broad Money Demand and Financial Liberalization in Greece
Author(s)

Hali J. Edison

Martina Copelman

Kari H. Eika

Neil R. Ericsson

Ragnar Nymoen

Martina Copelman

Shaghil Ahmed John H. Rogers

Chan Huh

Nita Ghei

Steven B. Kamin

Jeffrey A. Frankel

Sergio L. Schmukler

Nathan Sheets

Simona Boata

Jane T. Haltmaier

Allen B. Frankel

David E. Palmer

Neil R. Ericsson

Sunil Sharma

Please address requests for copies to International Finance Discussion Papers, Division of International Finance, Stop 24, Board of Governors of the Federal Reserve System, Washington, DC 20551. Email: graym@frb.gov. Fax: (202)736-5638. 


\section{International Finance Discussion Papers}

IFDP

Number

$\underline{\text { Titles }}$

$\underline{\text { Author(s) }}$

1996

545 Mexico's Balance-of-Payments Crisis: A Chronicle of Death Foretold

544 The Twin Crises: The Causes of Banking and Balance-of-Payments Problems

Graciela L. Kaminsky

Carmen M. Reinhart

543 High Real Interest Rates in the Aftermath of Disinflation: Is it a Lack of Credibility?

Graciela L. Kaminsky

Leonardo Leiderman

542 Precautionary Portfolio Behavior from a Life-Cycle Perspective

Carol C. Bertaut

Michael Haliassos

$541 \quad$ Using Options Prices to Infer PDF's for Asset Prices: An Application to Oil Prices During the Gulf Crisis

William R. Melick Charles P. Thomas

540 Monetary Policy in the End-Game to Exchange-Rate Based Stabilizations: The Case of Mexico

Steven B. Kamin

John H. Rogers

539 Comparing the Welfare Costs and the Initial Dynamics of Alternative Temporary Stabilization Policies

Martin Uribe

538 Long Memory in Inflation Expectations: Evidence from International Financial Markets

Joseph E. Gagnon

537 Using Measures of Expectations to Identify the Effects of a Monetary Policy Shock

Allan D. Brunner

$536 \quad$ Regime Switching in the Dynamic Relationship between the Federal Funds Rate and Innovations in

Chan Huh Nonborrowed Reserves

535 The Risks and Implications of External Financial Shocks: Lessons from Mexico

534 Currency Crashes in Emerging Markets: An Empirical Treatment

Jeffrey A. Frankel Andrew K. Rose

533 Regional Patterns in the Law of One Price: The Charles Engel Roles of Geography Vs. Currencies

John H. Rogers 


\section{International Finance Discussion Papers}

IFDP

Number

558

557

556

555

554

553

552

551

550

549

548

547

546 $\underline{\text { Titles }}$

1996

Stockholding Behavior of U.S. Households: Evidence from the 1983-89 Survey of Consumer Finances

Firm Size and the Impact of Profit-Margin Uncertainty on Investment: Do Financing Constraints Play a Role?

Regulation and the Cost of Capital in Japan: A Case Study

The Sovereignty Option: The Quebec Referendum and Market Views on the Canadian Dollar

Real Exchange Rates and Inflation in Exchange-Rate Based Stabilizations: An Empirical Examination

Macroeconomic State Variables as Determinants of Asset Price Covariances

The Tequila Effect: Theory and Evidence from Argentina

The Accumulation of Human Capital: Alternative Methods and Why They Matter

Alternatives in Human Capital Accumulation:

Implications for Economic Growth

More Evidence on the Link between Bank

Health and Investment in Japan

The Syndrome of Exchange-Rate-Based

Stabilization and the Uncertain Duration of

Currency Pegs

German Unification: What Have We Learned

from Multi-Country Models?

Returns to Scale in U.S. Production: Estimates and Implications
Author(s)

Carol C. Bertaut

Vivek Ghosal

Prakash Loungani

John Ammer

Michael S. Gibson

Michael P. Leahy

Charles P. Thomas

Steven B. Kamin

John Ammer

Martín Uribe

Murat F. Iyigun

Ann L. Owen

Murat F. Iyigun

Ann L. Owen

Michael S. Gibson

Enrique G. Mendoza

Martin Uribe

Joseph E. Gagnon

Paul R. Masson

Warwick J. McKibbin

Susanto Basu

John G. Fernald 